\title{
Identification and partial characterisation of a new protective antigen of Brucella abortus
}

\author{
SANDRA CESPEDES, EDILIA ANDREWS, HUGO FOLCH* and ANGEL OÑATE \\ Department of Microbiology, Faculty of Biological Sciences, Universidad de Concepción, Concepción and \\ *Department of Immunology, Faculty of Medicine, Universidad Austral, Valdivia, Chile
}

\begin{abstract}
Two novel Brucella abortus proteins were isolated from B. abortus strain RB51 and their immunological properties were determined. These proteins precipitated in the $40-60 \%$ saturated concentration range of ammonium sulphate and had a molecular mass of $32.2 \mathrm{kDa}$ and $22.9 \mathrm{kDa}$, respectively. Both were able to induce a strong in-vitro blast transformation in lymphoid cells obtained from mice previously sensitised with a crude brucella protein extract. The protection studies showed that the $22.9-\mathrm{kDa}$ protein used as a protective immunogen was as effective as the live $B$. abortus RB51 vaccine but the $32.2-\mathrm{kDa}$ protein had a poor protective effect under similar conditions. The aminoterminal sequence of the $22.9-\mathrm{kDa}$ and $32.2-\mathrm{kDa}$ proteins was determined and analysed in a database. The lack of homology with other known B. abortus proteins indicated that both proteins were novel antigens.
\end{abstract}

\section{Introduction}

Brucella abortus, a facultative intracellular pathogen, is the aetiological agent of brucellosis, a disease that affects man and several other animal species [1]. B. abortus is able to survive and replicate within the cells of the reticulo-endothelial system, thus avoiding the extracellular immune defence mechanisms of the host [2]. Therefore, as for all intracellular bacterial pathogens, a protective immune response against $B$. abortus requires the action of $\mathrm{T}$ lymphocytes that mediate cytotoxic effects or induce greater killing capacity in the macrophage population, which is activated to eliminate the pathogen [3]. It is currently accepted that the lipopolysaccharide (LPS) component of $B$. abortus induces a strong humoral response [4], whereas certain protein components induce the T-cell-mediated response responsible for the elimination of the pathogen from the infected host [5]. However, other studies indicate that different proteins purified from $B$. abortus produce different types of immune responses: some proteins induce production of high levels of interferongamma $(\mathrm{IFN}-\gamma)$ that clearly correlates with a cellular

Received 9 Feb. 1999; revised version accepted 28 July 1999.

Corresponding author: $\operatorname{Dr}$ A. Oñate (e-mail: aonate@ udec.cl). immune response, while others induce a pattern of cytokines more compatible with a humoral immune response [6]. Also, it has been observed that $B$. abortus proteins with low or medium molecular mass in the range 34-12 kDa are often the best inducers of cellmediated immune responses $[7,8]$. In this regard, an earlier study demonstrated that $\mathrm{Cu} / \mathrm{Zn}$ superoxide dismutase extracted from B. abortus induces a strong T-cell response with high levels of IFN $-\gamma$ production [9] and that this protein is able to protect mice against challenge with a pathogenic B. abortus strain [10]. Similarly, Splitter and colleagues, in experiments in mice, demonstrated that the purified ribosomal protein L 7/L 12 induces a pattern of cytokines that correlates with delayed-type hypersensitivity and a protective immune response $[3,5]$. For brucellosis, as well as for other infectious diseases, it is important to identify the molecules in the aetiological agent that are able to induce a defensive response. In the future, this knowledge may enable the implementation of new vaccine strategies such as the use of recombinant micro-organisms, peptides or DNA vaccination. At present, the preferred vaccine for bovine brucellosis is based on B. abortus RB51, a non-pathogenic mutant of B. abortus 2308, described by Schurig in 1991 [11]. Taking these considerations into account, the general objective of this work was to study and to identify proteins from B. abortus RB51 able to induce a protective cellular immune response. 


\section{$M$ aterials and methods}

Animals

Two-month-old female BALB/C mice were obtained from Biosonda SA (Santiago, Chile). They were kept under standard conditions in the animal house facilities.

\section{Bacterial strains}

B. abortus strains 2308 from our own culture collection and B. abortus RB51 [11], originally obtained from Virginia-Maryland Regional College of Veterinary Medicine (Virginia Polytechnic Institute and State University. Blacksburg, VA, USA), were used throughout. The bacterial cells were grown in aerobic conditions in Trypticase Soy B roth (Difco L aboratories, Michigan, USA) for $72 \mathrm{~h}$ at $37^{\circ} \mathrm{C}$ and later used for inoculation, protein purification or immunological analysis. For inoculation, the bacterial suspensions were adjusted spectrophotometrically to an OD corresponding to $1 \times 10^{4} \mathrm{cfu}$ of $\mathrm{B}$. abortus strain $2308 / \mathrm{ml}$ and $2 \times 10^{8} \mathrm{cfu}$ of B. abortus RB $51 / \mathrm{ml}$.

\section{Extraction, analysis and fractionation of $B$.} abortus RB51 protein

To extract the brucella protein for analysis, bulk culture of B. abortus RB51 was deposited by centrifugation, washed three times with $0.01 \mathrm{M}$ phosphate-buffered saline (PBS; pH 7.2) and inactivated with methanol $60 \%$ for $24 \mathrm{~h}$. After centrifugation, the cells were resuspended and kept for 1 day in a hypertonic salt solution $(1 \mathrm{M} \mathrm{NaCl}$ with $0.1 \mathrm{M}$ sodium citrate), sonicated, centrifuged at $27000 \mathrm{~g}$ and the supernate containing the protein was recovered. The crude $B$. abortus protein solution was dialysed for $48 \mathrm{~h}$ against PBS, and kept at $-30^{\circ} \mathrm{C}$ until use. B. abortus protein obtained in this way was tested for contamination with nucleic acids by spectrophotometry at $260 \mathrm{~nm}$ [12], for KDO by the thiobarbituric acid method [13] and for LPS content by the Limulus A moebocyte Lysate EToxate $\mathrm{K}$ it (Sigma), used according to the manufacturer's directions. The protein concentration was measured by the Pierce Coomassie protein assay reagent (Pierce, Rockford, USA.) with bovine serum albumin as standard [14]. As a first stage of fractionation, the brucella protein obtained was precipitated with ammonium sulphate $20 \%$ saturation, then centrifuged at $12000 \mathrm{~g}$ for $15 \mathrm{~min}$; the precipitate was dissolved and dialysed against PBS for $48 \mathrm{~h}$. The resulting supernate from ammonium sulphate $20 \%$, B. abortus protein precipitate, was further sequentially precipitated with $40 \%, 60 \%$ and $80 \%$ of saturated ammonium sulphate. In each case the protein obtained was dissolved and centrifuged at $12000 \mathrm{~g}$ to remove insoluble material. In some cases the fractions of $B$. abortus proteins that showed good capacity to induce blast transformation of sensitised cells in vitro were submitted to a second fractionation by ion-exchange chromatography on a 20$\mathrm{ml}$ carboxymethylcellulose column (Sigma). For this procedure, the column was washed with $50 \mathrm{ml}$ of starting buffer $(0.01 \mathrm{M}$ phosphate buffer, $0.1 \mathrm{M} \mathrm{NaCl}$, $\mathrm{pH}$ 7.2), then loaded with the brucella protein preparation and run at a flow rate of $0.5 \mathrm{ml} / \mathrm{min}$. The bound protein was eluted from the column with a linear gradient from $0.1 \mathrm{M}$ to $1 \mathrm{M} \mathrm{NaCl}$ in $0.01 \mathrm{M}$ phosphate buffer (wash buffer, $\mathrm{pH}$ 7.2). Protein was eluted in fractions emerging from $0.2 \mathrm{M}$ to $0.8 \mathrm{M} \mathrm{NaCl}$ and the protein content of each fraction was estimated spectrophotometrically at $280 \mathrm{~nm}$. Those fractions with high absorbance and corresponding to a single peak were pooled and analysed by SDS-PAGE. The protein peaks obtained were sterilised by filtration and kept frozen for use in lymphocyte proliferation or mouse protection studies.

\section{$\mathrm{N}$-terminal amino-acid sequencing}

Samples $(15 \mu \mathrm{g})$ of each of the semi-purified proteins from B. abortus RB51 were separated by SDS-PAGE and the protein bands were then electrophoretically transferred to polyvinylidene difluoride membrane (A pplied Biosystems, Foster City, CA, USA) [15]. The protein bands were visualised by staining the membrane for $1 \mathrm{~min}$ with Coomassie Brilliant Blue $0.1 \%$ and de-staining with methanol $50 \%$. The stained band was excised, and the $\mathrm{N}$-terminal amino acids sequenced by the method described by $M$ atsudaira [16]. The latter procedure was done at the Biotechnology Resource Laboratory, Medical University of South Carolina. Charleston, SC, USA, and the EMBL nucleic acid sequence database was used for homology searches.

\section{Lymphocyte proliferation assay}

This assay was performed as described previously [10]. $B$ riefly, mice were inoculated in the footpad with $25 \mu \mathrm{g}$ of B. abortus protein or PBS as control. In both cases the aqueous solution was emulsified in incomplete Freund's adjuvant (IFA; Sigma), and 7 days after immunisation the animals were killed by cervical dislocation. The popliteal lymph nodes were then removed and teased in cold tissue-culture medium. The cell suspension obtained was allowed to settle for $3 \mathrm{~min}$ to remove tissue particles and the free cells remaining in suspension were decanted and washed twice. The lymphocytes were next resuspended in RPMI 1640 medium containing fetal calf serum 10\% $\mathrm{v} / \mathrm{v}$, plus antibiotics, and cultured in 96-well plates at a concentration of $4 \times 10^{5}$ cells/well. They were cultured alone or in the presence of different amounts of B. abortus antigens. After culture for 3 days, the cells were pulsed with thymidine $(50 \mathrm{Ci} / \mathrm{mmol}$; A mersham, London) $0.4 \mu \mathrm{Ci} /$ well for $8 \mathrm{~h}$ and harvested on glass fibre filters. The thymidine incorporation was measured in each culture and was expressed as counts per minute obtained from triplicate cultures. 


\section{Protection experiments}

To test the induction of protection with different immunogens, groups of five mice each were vaccinated intraperitoneally (i.p.) with different preparations of $B$. abortus antigen or with $2 \times 10^{8}$ cfu of live $B$. abortus strain RB51 as positive control. Mice inoculated with PBS were used as negative controls. In all cases, the protein preparations and the control PBS were emulsified in IFA. Five weeks after vaccination all mice were challenged by i.p. injection of $10^{4} \mathrm{cfu}$ of $B$. abortus strain 2308. Experimentally infected mice were killed 2 weeks later by cervical dislocation, their spleens were disrupted and dilutions were plated to determine the number of $B$. abortus cfu/spleen [10]. The degrees of protection in vaccinated animals and controls were expressed as mean $\log _{10}$ cfu for spleens in each group obtained after challenge [17].

\section{Statistical analysis}

Statistical analyses were performed by Student's paired $t$ test. $\log _{10}$ units of protection were obtained by subtracting mean $\log _{10}$ cfu for the experimental group from the mean $\log _{10} \mathrm{cfu}$ of the corresponding control group [18].

\section{R esults}

Contaminants of the crude B. abortus protein preparation

Before fractionation, the nucleic acid and LPS contaminants in the crude B. abortus protein prepara- tion were determined. The results indicated that it contained $5 \%$ nucleic acids, $0.02 \% \mathrm{KDO}$ and $0.18 \mathrm{U}$ of endotoxin/mg of protein.

\section{Purification of two B. abortus proteins}

The isolation of two proteins from the crude $B$. abortus RB51 protein preparation was done in two steps. As a first step, brucella protein was precipitated with increasing concentrations of ammonium sulphate. Protein fractions that precipitated with $20 \%$ saturated ammonium sulphate and the resulting precipitates at $20-40 \%, 40-60 \%$ or $60-80 \%$ of saturation were analysed by SDS-PAGE and compared with the crude brucella protein preparation. The four fractions obtained showed minor differences in the protein pattern when compared with the total brucella proteins (Fig. 1a). The four precipitates obtained induced a lymphoproliferative response in cultures of popliteal lymph node cells obtained from mice immunised with brucella protein (Fig. 1b). Clearly, the fraction that precipitated at 40 and $60 \%$ saturated ammonium sulphate was the best inducer of blast transformation; therefore, this fraction was further purified by ion-exchange chromatography. The results of this separation indicated four peaks of material absorbing at $280 \mathrm{~nm}$ (Fig. 2a). Pooled fractions from peak $A$ showed one major band of $32.2 \mathrm{kDa}$ when analysed by SDS-PAGE (Fig. $2 \mathrm{~b}$, lane 5). Peak $B$ showed two protein bands of $32.2 \mathrm{kDa}$ and $22.9 \mathrm{kDa}$ (Fig. 2b, lane 4), whereas peak $C$ gave only one strong band of $22.9 \mathrm{kDa}$ (Fig. 2b, lane 7). Peak D did not reveal any defined protein band (Fig. 2b, lane 6). The lymphoproliferative response induced by proteins from peaks $A, B$ and $C$ with lymphocytes

a

b
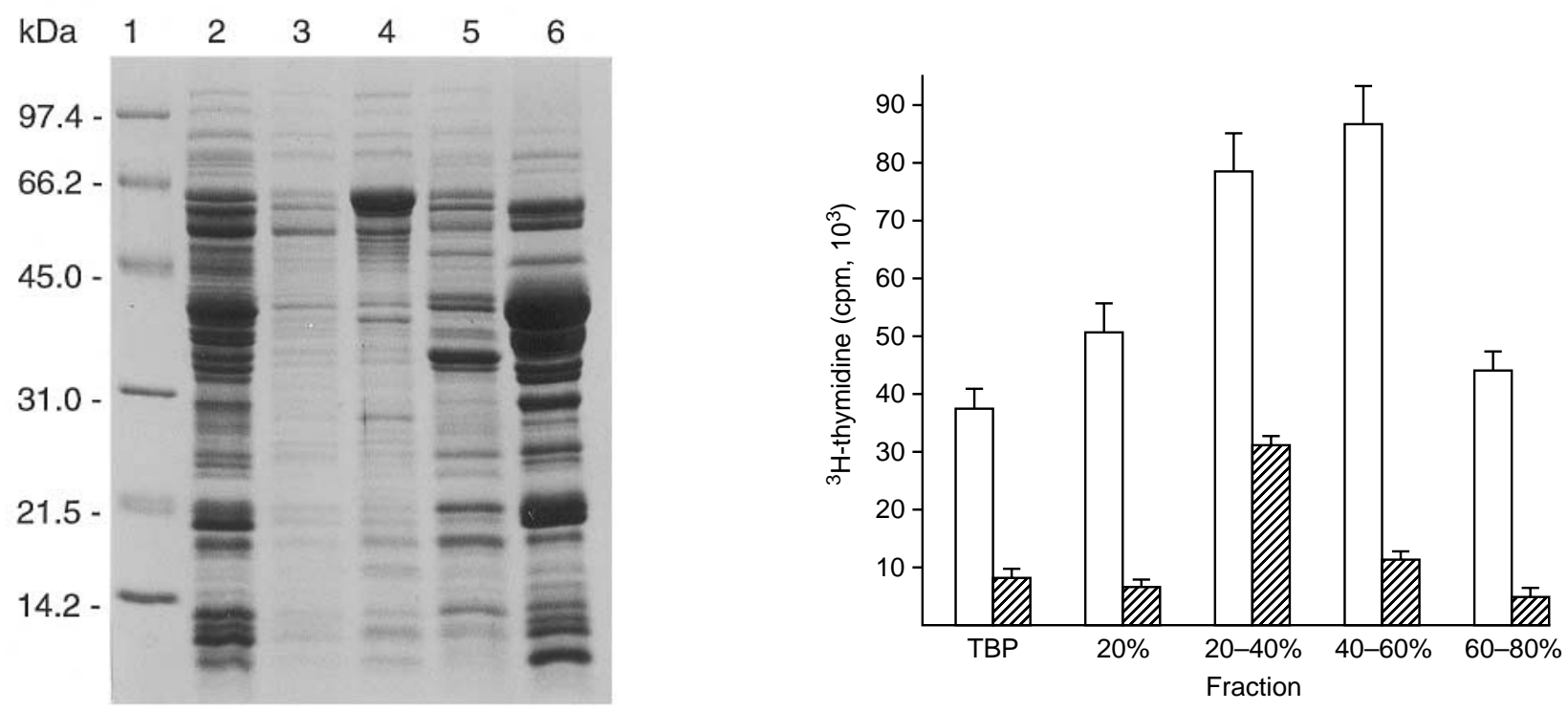

Fig. 1. (a) SDS-PAGE analysis of B. abortus protein (lane 2) and fractions precipitated with different concentrations of saturated ammonium sulphate: $3,20 \% ; 4,20-40 \% ; 5,40-60 \% ; 6,60-80 \%$. (b) Blast transformation capacity of the same fractions in lymph node cells obtained from immunised animals ( $\square$ ) or in lymphocytes obtained from nonimmunised animals (四). 
a

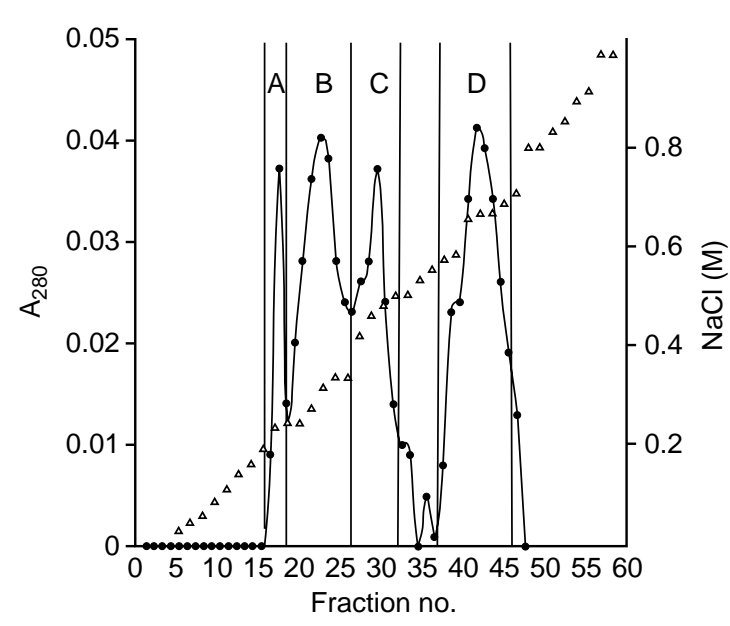

b

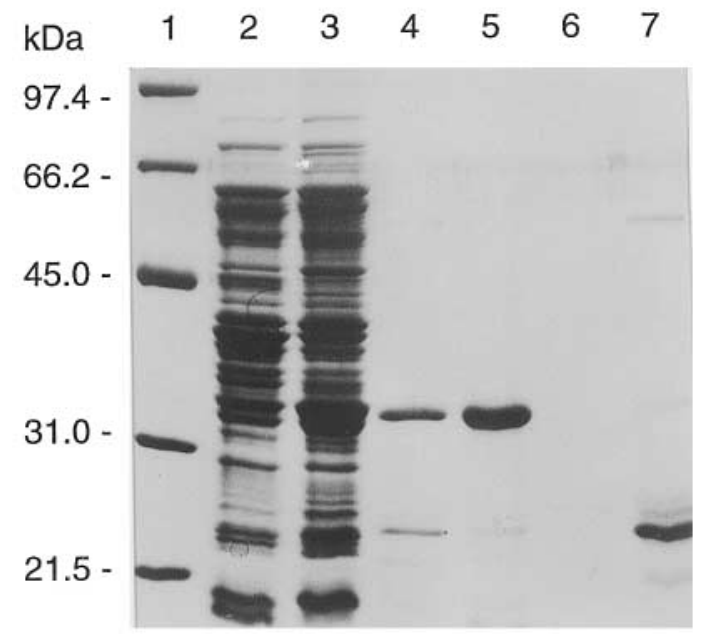

Fig. 2. (a) Elution diagram from ion-exchange chromatography of the crude $B$. abortus protein fraction that precipitated between 40 and $60 \%$ saturated ammonium sulphate, showing peaks $A, B, C$ and D with high $0 D_{280}$ readings. (b) SDSPAGE analysis of the protein content of peak A (lane 5), peak B (4), peak C (7) and peak D (6); (2) crude B. abortus protein; (3) crude B. abortus protein fraction precipitated between 40 and $60 \%$ saturated ammonium sulphate.

from mice previously sensitised with brucella protein was similar, but less than that observed when the lymphocytes were stimulated in vitro with brucella protein or with the proteins that precipitated between 40 and $60 \%$ saturated ammonium sulphate (Fig. 3).

\section{Protection assays}

The protection assays were done by immunising BALB/c mice with semi-purified $32.2-k D a$ or $22.9-$ $\mathrm{kDa}$ protein or crude brucella protein. PBS and viable

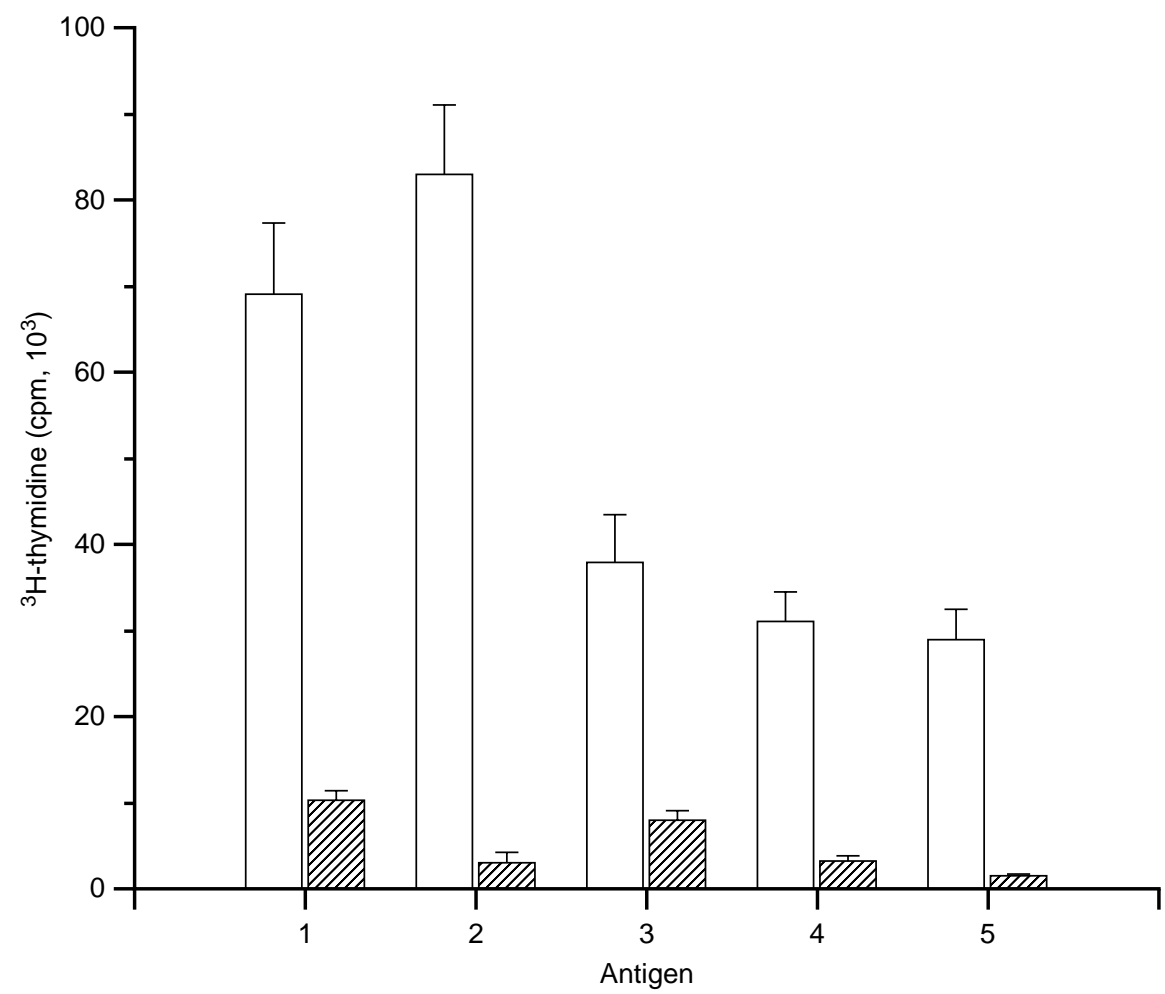

Fig. 3. Proliferative response of lymph node cells from mice immunised with total B. abortus protein ( $\square$ ) or nonimmunised controls ( $\mathbb{Q}$ ), cultured in the presence of total B. abortus protein (1), protein fraction precipitated with $40-$ $60 \%$ saturated ammonium sulphate (2) or the protein content of peak A (3), B (4) or C (5). 
Table 1. Protection of mice against challenge with B. abortus 2308 after immunisation with different antigens

\begin{tabular}{lcc}
\hline Vaccine and dose & $\begin{array}{c}\text { Mean (SD) } \log _{10} \text { cfu } \\
\text { of B. abortus } 2308 \text { in } \\
\text { spleen after challenge* }\end{array}$ & $\begin{array}{c}\log _{10} \text { units of } \\
\text { protection }\end{array}$ \\
\hline Saline control & $5.43(0.15)$ & 0 \\
Live RB $51\left(2 \times 10^{8} \mathrm{cfu}\right)$ & $3.58(0.67)$ & 1.85 \\
Total B. abortus protein $(30 \mu \mathrm{g})$ & $4.95(0.78)$ & 0.48 \\
$32.2-\mathrm{kDa}$ protein $(5 \mu \mathrm{g})$ & $4.60(0.45)$ & 0.83 \\
$22.9-\mathrm{kD}$ a protein $(5 \mu \mathrm{g})$ & $3.51(0.88)^{\dagger}$ & 1.92 \\
\hline
\end{tabular}

*Mice were challenged i.p. with $10^{4} \mathrm{cfu}$ of strain 23085 weeks after vaccination.

${ }^{\dagger} p<0.05$ compared with value for control mice.

B. abortus strain RB51 were used as negative and positive controls, respectively. Table 1 shows that, as might be expected, the strain RB51 live vaccine protected efficiently against the pathogenic challenge strain 2308. A similar effect was obtained with the 22.9-kDa protein that was able to induce a significant level of protection (1.92 $\log _{10}$ units) $(p<0.05)$ compared with the negative control inoculated with PBS. In contrast, the protection obtained with crude brucella protein or with the $32.2-\mathrm{kD}$ a protein was poor.

Amino-terminal sequence of $22.9-$ and $32.2-\mathrm{kDa}$ B. abortus proteins

The amino-terminal sequences of the 22.9- and 32.2$\mathrm{kDa}$ B. abortus proteins were determined as FRRPFRATPVQKDGP and AGESEVKVIVSGNAI, respectively. When these sequences were compared with the existing data in the EMBL nucleic acid sequence database, no sequences were found to be homologous with previously described B. abortus proteins, confirming that both proteins are new antigens not identified previously.

\section{Discussion}

The analysis of the crude B. abortus protein preparation showed that it contained only traces of endotoxin. This correlates well with the results obtained when the KDO content was measured. This small amount of LPS contamination makes it unlikely that the protection observed in this study was due to antibodies against this component of B. abortus. Moreover, if it is considered that the RB51 strain used in this study was essentially free of 0 -chain, it does not induce antibodies against the immunodominant epitopes located in the $\mathrm{N}$-acylated perosamine polymer of LPS, which is usually responsible for the specific antibodies produced in this disease and detected by standard serological tests $[11,19,20]$. Results not shown in this work indicated that mice immunised in the footpad with the crude extract of B. abortus RB51 protein or the purified proteins in IFA did not produce antibody against S-LPS or the crude protein preparation [21].

The blast transformation experiments showed that the two B. abortus proteins partially purified in this study were able to induce a significant cellular response in vitro, which indicates that these antigens were well recognised by the mice. Furthermore, if it is accepted that blast transformation correlates with a CD-4 T-cell response, it could be expected that these two proteins should have the capacity to induce a delayed-type hypersensitivity response, with a possible role in defence. However, the results of the protection assays demonstrated that the $22.9-\mathrm{kDa} \mathrm{B}$. abortus protein was far better than the $32.2-\mathrm{kDa}$ protein in this respect. This is consistent with previous observations that not all the protein components of B. abortus are good inducers of protection [22]. Antigen recognition, and even an immune response, in this case detected by lymphoproliferation assay, does not necessarily correlate with a protective response. In the present study both purified proteins were good inducers of lymphocyte proliferation in vitro, but only the lower mol. wt protein showed an important protective capacity when used as vaccine. It is important to state that the protective effect of the protein preparation was produced only when the antigen was injected as an emulsion in IFA, as described for the $\mathrm{Cu} / \mathrm{Zn}$ superoxide dismutase protein (Cu/Zn SOD) and some of its peptides [23]. As demonstrated by the amino-terminal sequence analysis, the two proteins have not been studied before and the results presented in this study showed that at least the $22.9-\mathrm{kDa}$ protein is a novel antigenic entity that deserves further attention.

This work was supported by FONDECYT grant 1961146 and grant 98.036.010-1.0 from Dirección de Investigación, Universidad de Concepción.

\section{R efer ences}

1. Corbel MJ. Brucellosis: an overview. Emerg Infect Dis 1997; 3: $213-221$

2. Pizarro-Cerdá J, M oreno E, Sanguedolce V, M ege J-L, Gorvel $J$-P. Virulent Brucella abortus prevents lysosome fusion and is distributed within autophagosome-like compartments. Infect Immun 1998; 66: 2387-2392.

3. Splitter G, Oliveira S, Carey M, Miller C, Ko J, Covert J. T lymphocyte mediated protection against facultative intracellular bacteria. Vet Immunol Immunopathol 1996; 54: 309-319.

4. Moreno $E, B$ erman DT, B oettcher LA. Biological activities of Brucella abortus lipopolysaccharides. Infect Immun 1981; 31: 362- 370.

5. Oliveira SC, Zhu Y, Splitter GA. Recombinant L7/L12 ribosomal protein and gamma-irradiated Brucella abortus induce a T-helper 1 subset response from murine $\mathrm{CD}^{+} \mathrm{T}$ cells. Immunology 1994; 83: 659-664. 
6. Zhan Y, Yang J, Cheers C. Cytokine response of T-cell subsets from Brucella abortus-infected mice to soluble Brucella proteins. Infect Immun 1993; 61: 2841-2847.

7. Stevens MG, Olsen SC, Cheville N-F. Lymphocyte proliferation in response to Brucella abortus RB51 and 2308 proteins in RB51-vaccinated or 2308-infected cattle. Infect Immun 1996; 64: 1007-1010.

8. Pugh GW, Tabatabai LB. Variation in Brucella abortus 2308 infection in BALB/C mice induced by prior vaccination with salt-extractable periplasmatic proteins from Brucella abortus 19. Infect Immun 1996; 64: 548-556.

9. Oñate $\mathrm{A}$, Folch $\mathrm{H}$. A $18.5 \mathrm{Kd}$ protein. An interesting antigen of Brucella. Arch Med Vet 1995; 27: 93-102.

10. Oñate $A$, Vemulapalli $R$, Andrews $E$, Schurig $G G$, Boyle $S$, Folch $\mathrm{H}$. Vaccination with live Escherichia coli expressing Brucella abortus $\mathrm{Cu} / \mathrm{Zn}$ superoxide dismutase protects mice against virulent B. abortus. Infect Immun 1999; 67: 986-988.

11. Schurig GG, Roop RM, Bagchi T, Boyle S, Buhrman D, Sriranganathan N. Biological properties of RB51; a stable rough strain of Brucella abortus. Vet Microbiol 1991; 28: 171- 188.

12. Walker JM. Nucleic acid. In: Clifton (ed) Methods in molecular biology. NJ, USA, Humana Press. 1984: 468.

13. Waravdekar VS, Saslaw LD. A method of estimation of 2deoxyribose. Biochim Biophys Acta 1957; 24: 439.

14. Smith PK, Krohn RI, Hermanson GT et al. Measurement of protein using bicinchonicic acid. Anal Biochem 1985; 150: 76-85.

15. Towbin H, Stahelin T, Gordon J. Electrophoretic transfer of proteins from polyacrylamide gels to nitrocellulose sheets: procedure and some applications. Proc Natl Acad Sci USA 1979; 76: 4350- 4354

16. Matsudaira P. Sequence from picomole quantities of proteins electroblotted on to polyvinylidene difluoride membranes. J Biol Chem 1987; 262: 10035-10038.

17. Jiménez de Bagüés $M P$, Elzer $P H$, Jones $S M$ et al. Vaccination with Brucella abortus rough mutant RB51 protects $B a l b / C$ mice against virulent strains of Brucella abortus, Brucella melitensis, and Brucella ovis. Infect Immun 1994; 62: 4990- 4996.

18. Snedecor GW, Cochran WG. Statistical methods, 8th edn. A mes, IO, Iowa State University. 1989.

19. Cheville NF, Stevens M G, Jensen AE, Tatum FM, Halling SM Immune response and protection against infection and abortion in cattle experimentally vaccinated with mutant strains of Brucella abortus. Am J Vet Res 1993; 54: 1591- 1597.

20. Stevens MG, Hennager SG, OIsen SC, Cheville NF. Serologic responses in diagnostic tests for brucellosis in cattle vaccinated with Brucella abortus 19 or RB51. J Clin Microbiol 1994; 32: 1065- 1066

21. Céspedes S. M Sc thesis, Universidad de Concepción, Concepción, Chile, 1998.

22. Stevens M G, Olsen SC, Cheville NF. Lymphocyte proliferation in response to immunodominant antigens of Brucella abortus 2308 and RB51 in strain 2308-infected cattle. Infect Immun 1994; 62: 4646-4649.

23. Stevens MG, Tabatabai LB, OIsen SC, Cheville NF. Immune responses to superoxide dismutase and synthetic peptides of superoxide dismutase in cattle vaccinated with Brucella abortus strain 19 or RB51. Vet Microbiol 1994; 41: 383-389. 